\title{
HEALTH AND SAFETY IN THE ATOMIC ENERGY AUTHORITY
}

T HE report of the Committee appointed under the chairmanship of Sir Alexander Fleck to review the organization of the Atomic Energy Authority as a whole for the control of health and safety* begins by describing the measures which the Committee considers essential. Safe technological practice, it believes, involves : (a) formulating codes of practice for design and operation based on experimental facts and experience; the special problems of nuclear energy require that preparation of the codes should be the responsibility of specialist health and safety staff; (b) designing plant using these codes of practice; this is the responsibility of design engineers; $(c)$ operating and maintaining the plant to these codes; the executive responsibility for this rests with the works general manager and his operating staff; $(d)$ overall monitoring of both design and operations by the safety staff, whose duty it is to direct the attention of the executive authority to any lapse from the prescribed codes.

The report next considers the functions of Government departments in this field and, after defining the Authority's role in relation to health and safety measures, the Authority's organization against this background. The national implications of the acute shortage of specialist health and safety staff in the field of nuclear energy to which the report directs attention, and the recommendations of the Committee in this connexion, and in regard to the Authority's external relations and responsibilities, are discussed elsewhere (p. 1023 of this issue). The internal recommendations are summarized below.

The Fleck Committee endorses the Authority's decision to establish a committee of the Atomic Energy Executive to be responsible for the overall supervision of all matters of health and safety, but recommends some minor changes in the terms of reference. It considers that the new committee * Atomic Energy Office. Report of the Committee appointed by the Prime Minister to examine the Organisation for Control of Healt and Safety in the United Kingdom Atomic Energy Authority. Pp. 28.
(Cmnd. 342.) (London: H.M. Stationery Office, 1958.) 18. 3d. net. structure established under the Executive Committee on Health and Safety provides an effective means of controlling health and safety throughout the Authority. Recommended terms of reference for the subordinate Weapons Safety Executive Committee, Safety Executive Committee and Health Executive Committee are suggested. It also recommends that the management of health and safety in the factories of the Industrial Group should be fully integrated into a single section responsible directly to the works general manager and endorses the new health and safety organization at Risley and the concept of an Authority Safety Branch which it contains. This organization, it is suggested, should be brought up to strength as a matter of urgency, and detailed terms of reference for the Industrial Group Health and Safety Branch are suggested covering the preparation of codes of practice, and provision of a medical service, radiological safety service and industrial safety service at each site, and provision of an independent inspection service.

The Committee recommends that there should be one senior member of the scientific staff at the Radiochemical Centre, whose principal duty would be functional responsibility to the manager for all safety matters. Existing members of the staff should be given this duty on a rota basis, and a first task of the new safety officer should be to investigate storage arrangements for radioactive materials. It is also recommended that the Authority should bring the site emergency procedures in each of its estab. lishments to a uniformly high standard. The procedures should be co-ordinated to ensure that the maximum technical resources of the whole Authority may be deployed to counter an emergency in any single establishment. Finally, there should be closer collaboration between the Authority's three Groups on the problems concerned with the control of criticality, and each Group should have a nominated officer to bear functional responsibility for eriticelity problems.

\section{INDUSTRIAL HEALTH IN GREAT BRITAIN}

\begin{abstract}
THE annual report* of the Chief Inspector of Factories for 1956 records a reduction of 2 per cent in the number of accidents, from 163,332 in 1955 to 160,116 , although the estimated number employed in factories increased by 0.4 per cent. The downward trend in the accident rate per thousand employed continued, as did the fatality rate per million employed (54), the number of fatal accidents in factories being 426 ; and of 184,785 accidents notified during the year from all premises subject to the Factories Acts, 687 were fatal. The Chief Inspector observes that probably greater efforts have never been made than during the past year to reduce the risk of accidents due to fire, and these efforts,

* Ministry of Labour and National Service. Annual Report of the Chief Inspector of Factories for the year 1956. Pp. 195. (Cmnd. 329.) (London: I.M. Stationery Office, 1958.) 98. 6d. net.
\end{abstract}

which are part of a continuing campaign carried out by the inspectorate, other Ministries, local authorities, fire services and various organizations, have been intensified, and co-operation between the authorities and services has been strengthened and extended.

The cardinal importance of the contribution of the scientist and technologist to health and safety in industry is again apparent from this report. Thus, reviewing progress on safety, the report stresses four aspects, in all of which that contribution is decisive. First, the need to design for safety. Secondly, the tendency for electrical and electronic apparatus to be included where formerly reliance was placed only on a mechanical system of control. Thirdly, and in consequence, greater reliability is required of such apparatus to ensure the safety of operators, since 
failure may lead to unexpected and dangerous movement. Accordingly, extensive studies are being undertaken of the reliability of complex electrical and electronic equipment, and there is every expectation that, in future, fault-finding will be made to some extent automatic, so that the production process may be kept going with a minimum of costly interruption. Fourthly, the problems of safety in the nuclear power stations are briefly reviewed (see p. 1023 of this issue).

There has been steady improvement in all fields of safety, and the Chief Inspector believes that accident prevention is gaining momentum, but that we need to set our sights a good deal higher. In referring to training in safety, he expresses the hope that the technical colleges will take greater interest, and that in the expanded programmes a place will be found for spreading the fundamental principles of safe working. The Clean Air Act, where it reduces the pollution of the atmosphere, has immediate repercussions on standards of cleanliness and lighting, and the Food Hygiene Regulations, 1955, have stimulated both food-products factories and factory canteens to further effort in clesnliness, both general and personal. Work continued on the surveys initiated by the Industrial Health Advisory Com. mittee into conditions affecting health, and that on the Halifax Survey was prectically completed during the year.

At the end of 1956, some 362 factories, including five receiving depleted uranium oxide from the Industrial Group of the Atomic Energy Authority at Risley, were receiving radioisotopes from Harwell and the Radiochemical Centre, Amersham, compared with 300 at the end of 1955, the most extensive use being for $\gamma$-radiography of castings, welds, etc., chiefly with iridium-192 and cobalt-60, though cæsium-137 continues to gain in favour. A draft code of regula. tions for the use of radioactive materials (other than for luminizing) was examined by an expert committee, and as a result draft regulations in respect of sealed sources were nearly complete by the end of the year and have since been published. The Radiological Protection Service made a concerted drive, with the Factory Inspectorate, to improve still further the protection of radium luminizers. The use of radioactive material for the elimination of static electrical charges continues to increase slowly.

\section{SCIENTIFIC AND TECHNICAL TRANSLATION}

\begin{abstract}
A CONEERENCE on "Scientific and Technical Translation", organized by Aslib, was held at the Connaught Rooms, London, W.C.2, on March 5. Dr. J. E. Holmstrom of Unesco and Mr. E. B. Uvarov were chsirmen for the morning and afternoon sessions respectively and about two hundred visitors attended. Mr. L. Wilson (director of Aslib) and Dr. Holmstrom introduced the subject, indicating that it had been examined in a report by Unesco* and was of increasing importance in facilitating scientific communication. Even if the problem were restricted to that experienced by those speaking English, it was found that about half of the world literature was unintelligible without translation. For those with other mother tongues the difficulties were far worse. The Unesco report contains the bulk of the factual information now available on translating methods, services, costs and indexes.
\end{abstract}

Three papers were presented: "The Organization and Availability of Technical Translation", by Dr. A. L. Mackay (Birkbeck College, London); "The Economics of Translation", by Mr. Felix Liebesny (Mond Nickel Company); and "Training for Translating Work", by Mr. A. G. Readett (National Coal Board, vice-chsirmen of the Institute of Linguists).

Dr. Mackay surveyed possible and actual methods of organizing the extraction of information from foreign-language literature, translation being regarded as an unproductive activity to be avoided if possible. The inefficiency of making a translation for one person who found only a fraction of it informative could be mitigated by circulating translations widely, regular cover-to-cover translations of major periodicals being the most systematic way of sharing expenses. Indexes of individual translations were thought to be only marginally useful. Persons properly qualified for scientific translation work would be better employed as full members of research and develop-

- "Scientific and Technical Translating and Other Aspects of the Language Problem". Unesco, 1957; second edition, 1958. (H.M. Stationery Office.) 208. ment groups working with linguistic and library rather than, say, chemical techniques. Material for translation should be selected for its value, reviews, digests and books being preferred; and an estimate of the premium to be placed on rapid processing could be made by attaching half-lives to various categories of literature. Training students in languages and maintaining scientific representatives abroad could reduce the volume of translation necessary.

Mr. Liebesny examined the actual costs, to an organization using translations, of various methods of preparation. He found that, where a complete text was required, the cost of translating a 1,000 word article from Russian to English was about $50 s$. to $120 s$., depending on particular techniques (use of recorder, typist, etc.) and salary rates. If the translator worked through the paper orally with the inquirer, translating only part, the cost could be reduced to $17 s$. to 28s. Mechanical translation, according to the most optimistic forecasts, might cost $2 s$. per thousand words. Under various co-operative schemes, such as that run by the Department of Scientific and Industrial Research, where the costs are shared, the charges might vary from $8 s$. to $30 s$. For cover-to-cover translations of periodicals the cost would be only $4 d$. to $6 d$., so that even assuming that only $2 \frac{1}{2}$ per cent of the papers which had to be bought were actually required and worth translating, the cost per thousand words would still be only $13 s$. to 20s. For such co-operative translations the choice of material is not wholly under the inquirer's control and certain pepers would still have to be dealt with individually.

Mr. Readett described how translators at the London office of the National Coal Board were trained to prepare abstracts, to make full translations and to provide interpreter services. Only professional linguists of honours degree standard were recruited and they were familiarized with the technology of the subject. The close and harmonious relations maintained with the Board's technicians were especially 